medRxiv preprint doi: https://doi.org/10.1101/2020.05.03.20089300; this version posted May 6, 2020. The copyright holder for this preprint (which was not certified by peer review) is the author/funder, who has granted medRxiv a license to display the preprint in perpetuity.

All rights reserved. No reuse allowed without permission.

2

3 Youenn Jouan ${ }^{1,2,3,4,9}$, Antoine Guillon ${ }^{1,2,3,8}$, Loïc Gonzalez ${ }^{1,2,8}$, Yonatan Perez ${ }^{1,2,3}$, Stephan

4 Ehrmann $^{1,2,3}$, Marion Ferreira ${ }^{2,5}$, Thomas Daix ${ }^{5}$, Robin Jeannet ${ }^{5}$, Bruno François ${ }^{5}$, Pierre-

\section{Functional alteration of innate $T$ cells in critically ill Covid-19 patients}

François Dequin ${ }^{1,2,3}$, Mustapha Si-Tahar ${ }^{1,2}$, Thomas Baranek ${ }^{1,2,7}$ and Christophe Paget ${ }^{1,2,7,9}$

${ }^{1}$ INSERM, Centre d'Etude des Pathologies Respiratoires (CEPR), UMR 1100, Tours, France. ${ }^{2}$ Université de Tours, Faculté de Médecine de Tours, France. ${ }^{3}$ Service de Médecine Intensive et Réanimation, Centre Hospitalier Régional Universitaire, Tours, France. ${ }^{4}$ Service de chirurgie cardiaque et de réanimation chirurgicale cardio-vasculaire, Centre Hospitalier Régional Universitaire, Tours, France. ${ }^{5}$ Intensive Care Unit, Dupuytren Teaching Hospital, Limoges, France; Inserm CIC1435, Dupuytren Teaching Hospital, Limoges, France; Inserm UMR 1092, University of Limoges, Limoges, France. ${ }^{5}$ Service de pneumologie, Centre Hospitalier Régional Universitaire, Tours, France.

${ }^{7,8}$ Contributed equally

${ }^{9}$ Correspondance should be address to: youenn.jouan@chu-tours.fr or christophe.paget@inserm.fr

Short title: Innate T cells in Covid-19

Keywords: innate T cells, inflammation, viral infection, Covid-19.

Number of words: 3,812

Abbreviations: Covid-19, Coronavirus disease 19; ICU, intensive care unit; IFN, interferon; IL, interleukin; MAIT, Mucosal associated invariant T; iNKT, invariant Natural Killer T.

NOTE: This preprint reports new research that has not been certified by peer review and should not be used to guide clinical practice. 
medRxiv preprint doi: https://doi.org/10.1101/2020.05.03.20089300; this version posted May 6, 2020. The copyright holder for this preprint (which was not certified by peer review) is the author/funder, who has granted medRxiv a license to display the preprint in perpetuity.

All rights reserved. No reuse allowed without permission.

35

36

37

38

39

40

41

42

43

44

45

50

51

52

53

54

55

56

57

58

59

60

61

62

63

64

65

66

67

68

\section{Abstract}

Covid-19 can induce lung infection ranging from mild pneumonia to life-threatening acute respiratory distress syndrome (ARDS). Dysregulated host immune response in the lung is a key feature in ARDS pathophysiology. However, cellular actors in Covid-19-driven ARDS are poorly understood. Here, we dynamically analyzed the biology of innate $\mathrm{T}$ cells, a heterogeneous class (MAIT, $\gamma \delta \mathrm{T}$ and iNKT cells) of $\mathrm{T}$ lymphocytes, presenting potent antiinfective and regulatory functions. Patients presented a compartmentalized lung inflammation paralleled with a limited systemic inflammation. Circulating innate $\mathrm{T}$ cells of critically ill Covid-19 patients presented a profound and persistent phenotypic and functional alteration. Highly activated innate T cells were detected in airways of patients suggesting a recruitment to the inflamed site and a potential contribution in the regulation of the local inflammation. Finally, the expression of the CD69 activation marker on blood iNKT and MAIT cells at inclusion was predictive of disease severity. Thus, patients present an altered innate $\mathrm{T}$ cell biology that may account for the dysregulated immune response observed in Covid-19-related acute respiratory distress syndrome.

(1)

4

55

6

57

8

9




\section{Introduction}

In December 2019 were first reported in Wuhan, China, pneumonia cases due to a coronavirus, the Severe Acute Respiratory Syndrome coronavirus 2 (SARS-CoV-2), a novel strain related to SARS-CoV and MERS-CoV, responsible for recent outbreaks. Disease presentation related with SARS-CoV-2 (Coronavirus disease, Covid-19), can vary from mild disease to lifethreatening acute respiratory distress syndrome (ARDS). ARDS is caused by a sustained and dysregulated immune response triggered in the lung after initial insult, resulting in alteration of alveolar-capillary membrane permeability and perturbed tissue repair ${ }^{1}$. This pathological process leads to interstitial and alveolar oedema that profoundly impairs gas exchange. However, the cellular and molecular factors that are responsible for this aberrant and persistent inflammatory response are poorly understood ${ }^{2}$. In SARS-CoV infection, delayed type I IFN response together with high viral loads were associated with defective adaptive response and exaggerated tissue damage ${ }^{3}$. During severe SARS-CoV-2 infection, elevated pro-inflammatory cytokines levels (e.g. IL-6 and TNF- $\alpha$ ) were associated with more severe cases, supporting an inflammatory hypothesis ${ }^{4-6}$. In addition, $T$ cell lymphopenia has been correlated with disease severity suggesting a role for these cells in the pathophysiology of severe Covid-19,6. Besides classical adaptative $\mathrm{CD} 4^{+}$and $\mathrm{CD} 8^{+} \mathrm{T}$ cells, the $\mathrm{T}$ cell compartment comprises several lineages of cells endowed with both innate and adaptive properties that are referred to as unconventional or innate $\mathrm{T}$ cells (iT cells) ${ }^{7}$. This heterogeneous class of $\mathrm{T}$ cells comprises three main lineages including Mucosal-Associated Invariant T (MAIT), $\gamma \delta \mathrm{T}$ and invariant Natural Killer T (iNKT) cells. They are restricted to quasi-monomorphic non-classical major histocompatibility complex and have emerged as key players in mucosal immunity and inflammatory response ${ }^{8-}$ ${ }^{11}$. Given their versatile functions, iT cells emerge as interesting targets in the context of Covid19-driven ARDS. First, iT cells mainly populate mucosal tissues including the lung and have the ability to promptly produce substantial amounts of inflammatory cytokines such as IFN- $\gamma$ and IL-17A, two key cytokines in anti-infective response at barrier sites. Moreover, iT cells can fine-tune the intensity and flavour of the host immune response shaping the magnitude of the adaptive response. They can also participate in the process of the resolution of inflammation including tissue repair and regeneration ${ }^{12-14}$, a critical step that is highly altered during ARDS. Despite these pivotal functions, the putative contribution of $\mathrm{iT}$ cells in the pathophysiological process of ARDS has never been explored.

Here, we dynamically assessed the relative frequencies and functions of iT cells in biological fluids of thirty patients with severe Covid-19 admitted to intensive care unit (ICU). Our analysis indicated that iT cells from critically ill Covid-19 patients displayed a phenotype of activated 
medRxiv preprint doi: https://doi.org/10.1101/2020.05.03.20089300; this version posted May 6, 2020. The copyright holder for this preprint (which was not certified by peer review) is the author/funder, who has granted medRxiv a license to display the preprint in perpetuity.

All rights reserved. No reuse allowed without permission.

103 cells associated with changes in their cytokine profile. Importantly, activated iT cells populated

104 the airways of patients presenting a strong local inflammation. In addition, the activation status

105 of blood iT cells on admission was predictive of the level of hypoxia during the course of

106 infection. Thus, our study indicates that an alteration in iT cell biology may account for the

107 sustained host immune response dysregulation observed in Covid-19-driven ARDS.

108

109

110

111

112

113

114

115

116

117

118

119

120

121

122

123

124

125

126

127

128

129

130

131

132

133

134

135

136 
medRxiv preprint doi: https://doi.org/10.1101/2020.05.03.20089300; this version posted May 6, 2020. The copyright holder for this preprint (which was not certified by peer review) is the author/funder, who has granted medRxiv a license to display the preprint in perpetuity.

\section{Results and Discussion}

Lymphopenia and compartmentalized lung inflammation characterized critically ill Covid-

\section{9 patients}

Thirty patients admitted in ICU for severe Covid-19 were included. Baseline characteristics of the patients are presented in Table 1. Median duration of symptoms before admission in ICU was 10 days $(8 ; 14)$, and ultimately, 24 patients $(80 \%)$ required invasive mechanical ventilation (20 at admission). Among these mechanically ventilated patients, all presented an ARDS, 21 (70\%) received neuromuscular blockade, $18(60 \%)$ were placed on prone position and one patient required extra-corporeal membrane oxygenation. On CT scan, we observed typical bilateral diffuse ground-glass lesions in severe Covid-19 patients (Supplementary Figure 1A). Upon enrolment, most of Covid-19 patients (22/30) presented mild to severe lymphopenia (0.75 $\mathrm{x} 10^{9} / \mathrm{L} \pm 0.06$ ) (Figure 1A) accompanied by a higher neutrophil-to-lymphocyte ratio as compared to age- and sex-matched controls (Figure 1B). As reported ${ }^{15}$, we observed a positive correlation between the degree of lymphopenia and the Sequential Organ Failure Assessment (SOFA) score (Figure 1C). Similarly, the lymphopenia was more pronounced in patients under invasive mechanical ventilation as compared to patients who did not require invasive mechanical ventilation (Figure 1D). Among the 30 critically ill Covid-19 patients, one died at day 2 after inclusion and 14 (46.7\%) were still in ICU at day 15, including 9 still under invasive mechanical ventilation. The remaining 15 patients improved and were discharged from ICU to other wards.

Although the circulating levels of the inflammatory mediators IL-1 $\beta$ and IL- 6 were significantly higher in Covid-19 patients as compared to age- and sex-matched controls (Figure 1E), the detected amounts were relatively low, as previously reported ${ }^{6}$. Of note, the levels of plasma IL1RA were high suggesting an active anti-inflammatory process (Supplementary Figure 1B). As judged by IFN- $\alpha 2$ levels, the type I IFN response, a critical component of the anti-viral response ${ }^{16}$ was also low in the blood compartment of patients as compared to controls (Figure 1E). To monitor the local inflammation, we analyzed the same mediators in the supernatants of endotracheal aspirates (ETA) of matched Covid-19 patients (Figure 1E). Strikingly, the amounts of IL-6, IL-1 $\beta$ and to a lesser extent IFN- $\alpha 2$ were sky high in the airways suggesting an intense local inflammation upon ICU admission (Figure 1F). Collectively, our data indicate 
medRxiv preprint doi: https://doi.org/10.1101/2020.05.03.20089300; this version posted May 6, 2020. The copyright holder for this preprint (which was not certified by peer review) is the author/funder, who has granted medRxiv a license to display the preprint in perpetuity.

All rights reserved. No reuse allowed without permission.

Blood innate $T$ cell decrease in Covid-19 patients is paralleled with their presence in the airways

While a T cell lymphopenia has been described in severe Covid-19 patients ${ }^{6}$, the innate $\mathrm{T}$ cell compartment has not been investigated yet. Detailed analysis of circulating iT cells within total T lymphocytes indicated a profound decrease in MAIT ( 6-fold) and iNKT ( 7-fold) relative proportions in critically ill Covid-19 patients (Figure 2A) despite some comorbidities such as obesity and/or diabetes can also partly contribute to this observation ${ }^{17,18}$. In the meantime, the relative proportion of $\gamma \delta$ T cells remained unchanged (Figure 2A). However, by focusing on subsets based on TCR repertoire, we observed that the frequency of $\mathrm{V} \delta 2^{+}$was slightly decreased while the V $\delta 1 \delta 2^{-}$cells were increased (Figure 2A). Of note, no significant differences could be observed for the $\mathrm{V} \delta 1^{+}$subset (Figure 2A). This may indicate a particular contribution of this $\gamma \delta \mathrm{T}$ subset - likely $\mathrm{V} \delta 3^{+}$- during Covid-19 as suggested in other viral infections ${ }^{18}$.

The decrease in circulating MAIT and iNKT cells may have multiple causes. First, we interrogated whether this could be a consequence of activation-induced TCR internalization. However, mean fluorescence intensity for TCR expression indicated no modulation for the iNKT TCR between patients and controls (Supplemental Figure 2A) while an increase intensity was observed for the MAIT TCR of patients. In addition, the levels of intracellular TCR Va7.2 expression in $\mathrm{T}$ cells of patients did not indicate any signs of MAIT TCR internalization (Supplemental Figure 2B).

Another explanation could be their migration into the airways of patients. Thus, we monitored the putative presence of iT cells in ETA of Covid-19 patients under mechanical ventilation (Table 1). We were able to recover cells - containing more than $1 \%$ of lymphocytes - in 12 ETA samples out of 21 , enabling a further analysis of iT cells. MAIT and $\gamma \delta \mathrm{T}$ cells were detected in airways of all patients with an analysable lymphocyte compartment (Figure 2B). Of note, airway iNKT cells were virtually undetectable in all samples. Interestingly, the frequency of MAIT cells but not of $\gamma \delta$ T cells was higher in the airways as compared to blood of matched-patients (Figure 2B) suggesting that the presence of MAIT cells in the airways might be dependent on an active recruitment mechanism rather than blood vessel leakage due to the alveolar-capillary barrier disruption. Furthermore, the presence of iT cells in ETA was associated with a higher level of the chemoattractants for T cells CXCL10 and CXCL12 ${ }^{19}$ (Figure 2C). Of note, one could argue that other causes such as increased cell death might account in this phenomenon ${ }^{20}$. Altogether, these data indicate a decrease in circulating MAIT and iNKT cells that may be a consequence of their recruitment into the airways. 
medRxiv preprint doi: https://doi.org/10.1101/2020.05.03.20089300; this version posted May 6, 2020. The copyright holder for this preprint (which was not certified by peer review) is the author/funder, who has granted medRxiv a license to display the preprint in perpetuity.

All rights reserved. No reuse allowed without permission.

\section{Innate T cells displayed an altered functional profile in Covid-19 patients}

Phenotypic analysis of iT cell in blood of Covid-19 patients showed an increased expression of the activation marker CD69 in all subsets (Figure 3A). This phenotype was associated with a higher level of IL-18 in the plasma of patients (Supplemental Figure 3), a cytokine associated to iT cell activation during viral infections ${ }^{21-23}$. In parallel, we observed an increased level of blood PD-1-expressing iT cells in patients suggesting a certain level of exhaustion (Figure 3A). Of importance, the levels of CD69 and PD-1-expressing MAIT and $\gamma \delta \mathrm{T}$ cells were significantly higher in ETA compared to blood in matched patients (Figure 3B), which further support the possible migration of activated blood iT cells into the lungs.

In addition, cytokine production by fresh blood iT cells was analyzed after short-term PMA/ionomycin stimulation. Circulating MAIT and iNKT, and to a lesser extent $\gamma \delta \mathrm{T}$ cells from Covid-19 patients produced less IFN- $\gamma$ as compared to cells from healthy donors (Figure 3C). In the meantime, this was paralleled with an increased ability of iT cells from patients to produce IL-17A (Figure 3C) although the levels detected were relatively low. This could be partially explained by the migration of IFN- $\gamma$-producing iT cells to the lung tissue. In line with the acute inflammation in the lung of Covid-19 patients $^{24}$, the levels of IFN- $\gamma$ and IL-17A were more elevated in the supernatants of ETA compared to plasma of matched patients (Figure 3D). Interestingly, they were present at higher concentration in iT cell-containing ETA samples (Figure 3E) suggesting that iT cells may contribute to the production of IFN- $\gamma$ and IL-17A in airways of critically ill Covid-19 patients. Collectively, our data indicate a functional alteration of iT cells in Covid-19 patients.

\section{Alteration in innate T cell biology is persistent and correlates with disease severity}

To gain insight into their temporal changes during Covid-19, the frequency and phenotype of blood iT cells was monitored in patients during their stay in the ICU. We observed a decrease in the frequency of MAIT cells at day 7 and then it was maintained to day 14 (Figure 4A). The proportion of CD69- and PD-1-expressing MAIT cells followed a similar trend (Figure 4A). The relative proportion of circulating iNKT cells was stable in critically ill Covid-19 patients during their stay in ICU regardless of their clinical course (Figure 4B). The level of CD69expressing iNKT cells was reduced at day 7 and 14 while no significant changes could be observed for PD-1 expression on iNKT cells while (Figure 4B). Similar to MAIT cells, the relative proportion of $\gamma \delta \mathrm{T}$ cells in was reduced at day 7 and a further decrease was noticed at day 14 (Figure 4C). Regarding their phenotype, the levels of circulating PD-1-expressing $\gamma \delta \mathrm{T}$ 
medRxiv preprint doi: https://doi.org/10.1101/2020.05.03.20089300; this version posted May 6, 2020. The copyright holder for this preprint (which was not certified by peer review) is the author/funder, who has granted medRxiv a license to display the preprint in perpetuity.

All rights reserved. No reuse allowed without permission.

237 cells was stable in patients while the relative proportion of their CD69-expressing counterparts 238 was decreased at day 7 and 14 (Figure 4C).

239 Finally, we interrogated whether alterations in iT cell biology could be predictive of the clinical 240 course of critically ill Covid-19 patients especially regarding the level of hypoxia, measured by 241 the $\mathrm{PaO}_{2} / \mathrm{FiO}_{2}$ ratio, a routine clinical variable for ARDS management ${ }^{1}$. Thus, we compared 242 multiple iT cell parameters on admission to the level of hypoxia at day 7. Although no 243 correlation could be observed for $\gamma \delta$ T cells, we observed that CD69 expression on MAIT and 244 iNKT cells was positively correlated to the $\mathrm{PaO}_{2} / \mathrm{FiO}_{2}$ ratio indicating a reduced level of hypoxia (Figure 4D). Notably, no additional correlation could be observed for MAIT and iNKT

246 cells based on the other iT cell-related parameters including PD-1 expression and cytokine 247 production.

248 Altogether, these data indicate a persistent alteration in iT cell activation in Covid-19 patients 249 and the levels of activation on MAIT and iNKT cells upon admission can be predictive of 250 disease severity. 
medRxiv preprint doi: https://doi.org/10.1101/2020.05.03.20089300; this version posted May 6, 2020. The copyright holder for this preprint (which was not certified by peer review) is the author/funder, who has granted medRxiv a license to display the preprint in perpetuity.

\section{Clinical study design, patient population and approval}

Patients (>18 years old) admitted in ICU with positive SARS-CoV-2 RT-PCR testing were prospectively included in this study, from March $18^{\text {th }} 2020$ to April $17^{\text {th }} 2020$. The study was conducted in one ICU from an academic hospital (Tours, France). All patients or their next of kin gave consent for participation in the study. This work was part of an ongoing study exploring immune response during community-acquired pneumonia (ClinicalTrial.gov identifier: NCT03379207). The study was approved by the ethic committee "Comité de Protection de Personnes Ile-de-France 8" under the agreement number 2017-A01841-52, in accordance with the national laws. Blood samples from healthy volunteers (age- and sexmatched) were obtained from the "Etablissement Français du Sang".

\section{Reagents and antibodies}

Staining was performed using antibodies (Table S1) from Biolegend (San Diego, CA, USA) and Miltenyi Biotec (Bergish Gladbach, Germany). PBS-57 glycolipid-loaded and control CD1d tetramers (BV421-conjugated) as well as 5-OP-RU-loaded and control MR1 tetramers (BV421-conjugated) were obtained from the National Institute of Allergy and Infectious Diseases Tetramer Facility (Emory University, Atlanta, GA). Dead cells were stained with LIVE/DEAD® Fixable Aqua Dead Cell Stain kit (ThermoFisher Scientific, Illkirch, France).

\section{Human cell isolation}

\section{$274 \quad P B M C$}

Peripheral Blood Mononuclear Cells (PBMC) were enriched by density gradient centrifugations using Histopaque-1077 solution (Sigma-Aldrich) according to the manufacturer's instructions. Red blood cells were removed using a red blood cell lysis buffer (Sigma-Aldrich).

\section{Endotracheal aspirates (ETA)}

ETAs were collected from Covid-19 patients who were under invasive mechanical ventilation. Then, ETAs were weighted and incubated in PBS ( $5 \mathrm{ml} / \mathrm{g}$ ) with $1 \mathrm{mM}$ Dithiothreitol for $30 \mathrm{~min}$ at $4^{\circ} \mathrm{C}$ under gentle agitation. After centrifugation, supernatants were collected and cell pellets 
medRxiv preprint doi: https://doi.org/10.1101/2020.05.03.20089300; this version posted May 6, 2020. The copyright holder for this preprint (which was not certified by peer review) is the author/funder, who has granted medRxiv a license to display the preprint in perpetuity.

All rights reserved. No reuse allowed without permission.

cell lysis buffer and then cells from ETA were passed through a $40 \mu \mathrm{m}$ cell strainer prior staining for flow cytometry.

\section{Cytokine measurement}

Cytokines were measured in sera and supernatants of ETA using the Bio-Plex Pro Human cytokines screening panel (Bio-Rad, Marnes-la-Coquette, France) in a multiplex fluorescent bead assay (Luminex), according to the manufacturer's instructions.

\section{Flow cytometry}

Cells were stained with antibodies to surface epitopes and viability dye (LIVE/DEAD Fixable Aqua Dead Cell Stain). For cytokine profile analysis, cells were stimulated for $4 \mathrm{~h}$ in RPMI1640 complete medium containing PMA $(100 \mathrm{ng} / \mathrm{ml})$ and ionomycin $(1 \mu \mathrm{g} / \mathrm{ml})$ in presence of protein transport inhibitor cocktail (eBioscience) added 1 hour after stimulation. For intracellular staining, cells were fixed and permeabilized using the Fixation/Permeabilization Solution Kit (BD Biosciences). Cells were stained with APC-conjugated mAb against IL-17A and PEconjugated mAb against IFN- $\gamma$. Events were acquired on a MACS Quant (Miltenyi Biotec) cytometer. Analyses were performed by using the VenturiOne software (Applied Cytometry; Sheffield, UK).

\section{Statistical analysis}

All statistical analysis was performed by using GraphPad Prism software. The statistical significance was evaluated by using non-parametric unpaired Mann-Whitney $U$ tests in order to compare the means of biological replicates in each experimental group. In some cases, the non-parametric Wilcoxon matched-pairs signed rank test was used. Results with a $\mathrm{P}$ value of $<0.05$ were considered significant. ns: not significant; * $\mathrm{p}<0.05 ; * * \mathrm{p}<0.01$; *** $\mathrm{p}<0.001$.). Correlation calculation between two parameters has been performed using the Spearman's rho test.

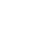


medRxiv preprint doi: https://doi.org/10.1101/2020.05.03.20089300; this version posted May 6,2020 . The copyright holder for this preprint (which was not certified by peer review) is the author/funder, who has granted medRxiv a license to display the preprint in perpetuity.

\section{Author contributions}

320 Y.J., A.G., S.E., P-F.D., M.S., T.B. and C.P. designed the research; L.G., Y.P., M.F., T.D., R.J., 321 T.B. and C.P collected the data; Y.J., L.G., T.B. and C.P. analysed the data; Y.J. and C.P. wrote 322 the manuscript with the input of all authors.

\section{Acknowledgments}

325 This work was supported by the Agence Nationale de la Recherche "JCJC program" (ANR-19326 CE15-0032-01) and by the Fondation du Souffle, with the "Fond de recherche en Santé 327 Respiratoire". M.S. and C.P. are supported by Inserm. Y.J., A.G., Y.P., S.E. and P-F.D. were 328 supported by the CHU of Tours. M.F., T.B. and L.G. are supported by the University of Tours. 329 We thank the NIH tetramer core facility (Emory University) for providing CD1d tetramers. We 330 acknowledge all healthcare co-workers involved in the ICU department at the Bretonneau 331 Hospital, especially Aurélie Aubrey, Delphine Chartier, Véronique Siméon and Julien 332 Bontemps for their excellent management of patient samples and clinical data. Annick Legras, 333 Denis Garot, Emmanuelle Mercier, Charlotte Salmon-Gandonnière, Laetitia Bodet-Contentin, 334 Marlène Morisseau, Stephan Mankikian and Walid Darwiche are acknowledged for patient inclusions. We thank all the patients and their families for their trust and confidence in our work. 
medRxiv preprint doi: https://doi.org/10.1101/2020.05.03.20089300; this version posted May 6, 2020. The copyright holder for this preprint (which was not certified by peer review) is the author/funder, who has granted medRxiv a license to display the preprint in perpetuity.

\section{References}

1. Thompson BT, Chambers RC, Liu KD. Acute Respiratory Distress Syndrome. N Eng1 J Med. 2017;377(6):562-572. doi:10.1056/NEJMra1608077

2. Matthay MA, Zemans RL, Zimmerman GA, et al. Acute respiratory distress syndrome. Nat Rev Dis Primers. 2019;5(1):18. doi:10.1038/s41572-019-0069-0

3. Channappanavar R, Fehr AR, Vijay R, et al. Dysregulated Type I Interferon and Inflammatory Monocyte-Macrophage Responses Cause Lethal Pneumonia in SARS-CoVInfected Mice. Cell Host Microbe. 2016;19(2):181-193. doi:10.1016/j.chom.2016.01.007

4. Mehta P, McAuley DF, Brown M, et al. COVID-19: consider cytokine storm syndromes and immunosuppression. Lancet. 2020;395(10229):1033-1034. doi:10.1016/S01406736(20)30628-0

5. Qin C, Zhou L, Hu Z, et al. Dysregulation of immune response in patients with COVID19 in Wuhan, China. Clin Infect Dis. March 2020. doi:10.1093/cid/ciaa248

6. Chen $\mathrm{G}, \mathrm{Wu} \mathrm{D}, \mathrm{Guo} \mathrm{W}$, et al. Clinical and immunological features of severe and moderate coronavirus disease 2019. J Clin Invest. April 2020. doi:10.1172/JCI137244

7. Godfrey DI, Uldrich AP, McCluskey J, Rossjohn J, Moody DB. The burgeoning family of unconventional T cells. Nat Immunol. 2015;16(11):1114-1123. doi:10.1038/ni.3298

8. Crosby CM, Kronenberg M. Tissue-specific functions of invariant natural killer T cells. Nat Rev Immunol. 2018;18(9):559-574. doi:10.1038/s41577-018-0034-2

9. Toubal A, Nel I, Lotersztajn S, Lehuen A. Mucosal-associated invariant T cells and disease. Nat Rev Immunol. 2019;19(10):643-657. doi:10.1038/s41577-019-0191-y

10. McCarthy NE, Eberl M. Human $\gamma \delta$ T-Cell Control of Mucosal Immunity and Inflammation. Front Immunol. 2018;9:985. doi:10.3389/fimmu.2018.00985

11. Trottein F, Paget C. Natural Killer T Cells and Mucosal-Associated Invariant T Cells in Lung Infections. Front Immunol. 2018;9:1750. doi:10.3389/fimmu.2018.01750

12. Nielsen MM, Witherden DA, Havran WL. $\gamma \delta$ T cells in homeostasis and host defence of epithelial barrier tissues. Nat Rev Immunol. 2017;17(12):733-745. doi:10.1038/nri.2017.101 13. Hinks TSC, Marchi E, Jabeen M, et al. Activation and In Vivo Evolution of the MAIT Cell Transcriptome in Mice and Humans Reveals Tissue Repair Functionality. Cell Rep. 2019;28(12):3249-3262.e5. doi:10.1016/j.celrep.2019.07.039

14. Paget C, Trottein F. Mechanisms of Bacterial Superinfection Post-influenza: A Role for Unconventional T Cells. Front Immunol. 2019;10:336. doi:10.3389/fimmu.2019.00336

15. Katze MG, He Y, Gale M. Viruses and interferon: a fight for supremacy. Nat Rev Immunol. 2002;2(9):675-687. doi:10.1038/nri888 
medRxiv preprint doi: https://doi.org/10.1101/2020.05.03.20089300; this version posted May 6, 2020. The copyright holder for this preprint (which was not certified by peer review) is the author/funder, who has granted medRxiv a license to display the preprint in perpetuity.

All rights reserved. No reuse allowed without permission.

372 16. Magalhaes I, Pingris K, Poitou C, et al. Mucosal-associated invariant T cell alterations

373 in obese and type 2 diabetic patients. J Clin Invest. 2015;125(4):1752-1762.

374 doi:10.1172/JCI78941

375 17. Lynch L, O’Shea D, Winter DC, Geoghegan J, Doherty DG, O'Farrelly C. Invariant 376 NKT cells and CD1d(+) cells amass in human omentum and are depleted in patients with cancer 377 and obesity. Eur J Immunol. 2009;39(7):1893-1901. doi:10.1002/eji.200939349

378 18. Mackay CR. Chemokine receptors and T cell chemotaxis. J Exp Med. 1996;184(3):799379 802. doi:10.1084/jem.184.3.799

380 19. Tyznik AJ, Verma S, Wang Q, Kronenberg M, Benedict CA. Distinct requirements for 381 activation of NKT and NK cells during viral infection. J Immunol. 2014;192(8):3676-3685. 382 doi:10.4049/jimmunol.1300837

383 20. Loh L, Wang Z, Sant S, et al. Human mucosal-associated invariant T cells contribute to 384 antiviral influenza immunity via IL-18-dependent activation. Proc Natl Acad Sci USA. 385 2016;113(36):10133-10138. doi:10.1073/pnas.1610750113

386 21. Tsai C-Y, Liong KH, Gunalan MG, et al. Type I IFNs and IL-18 regulate the antiviral 387 response of primary human $\gamma \delta \mathrm{T}$ cells against dendritic cells infected with Dengue virus. $\mathrm{J}$ 388 Immunol. 2015;194(8):3890-3900. doi:10.4049/jimmunol.1303343

389 22. Coronaviridae Study Group of the International Committee on Taxonomy of Viruses. 390 The species Severe acute respiratory syndrome-related coronavirus: classifying 2019-nCoV and 391 naming it SARS-CoV-2. Nat Microbiol. 2020;5(4):536-544. doi:10.1038/s41564-020-0695-Z 
Figures:

A

E
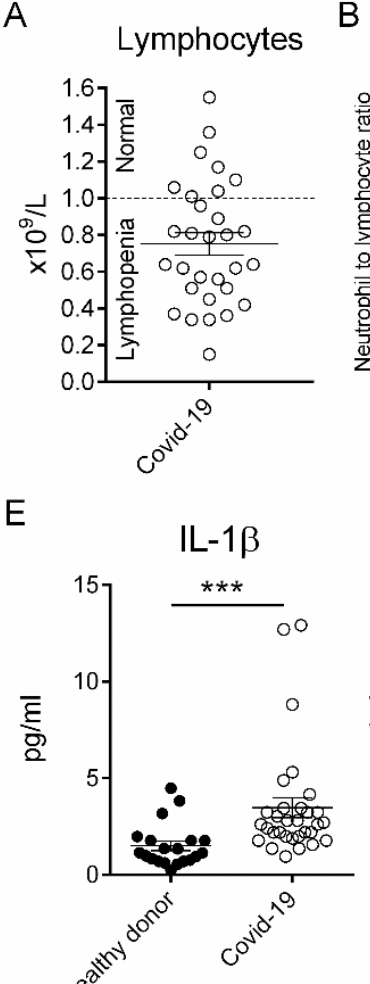

$\mathrm{F}$

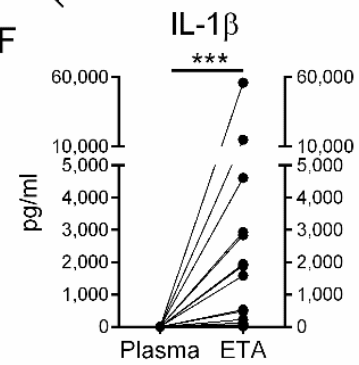

B
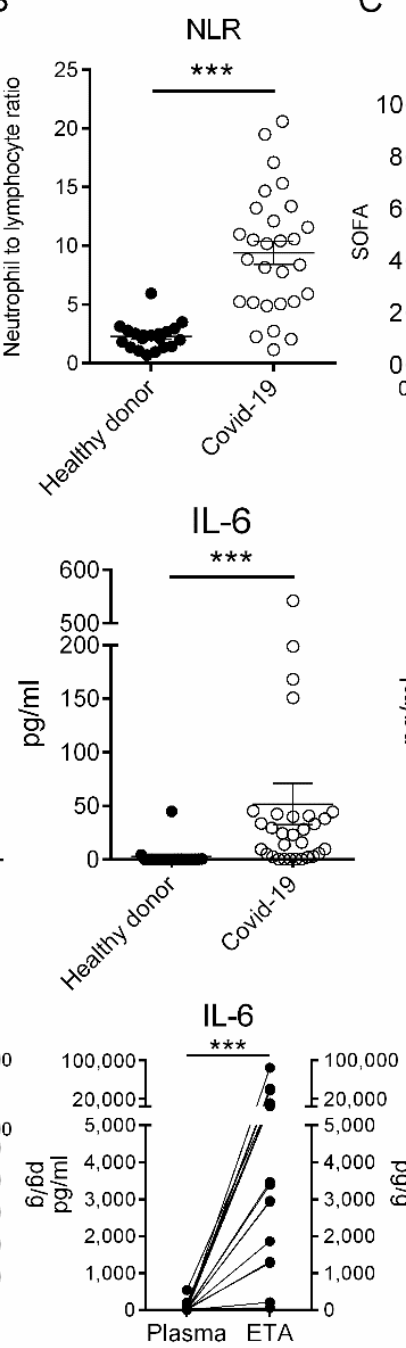

C

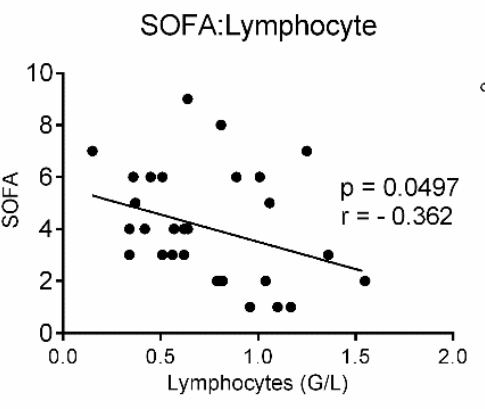

D Lymphocyte count
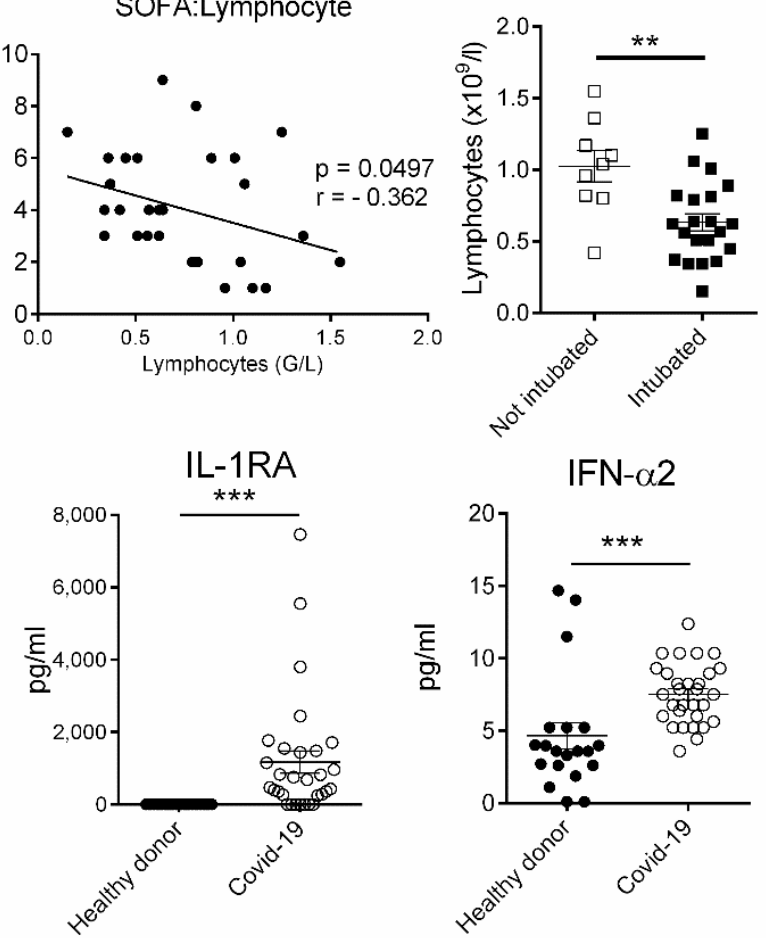

IL-1RA

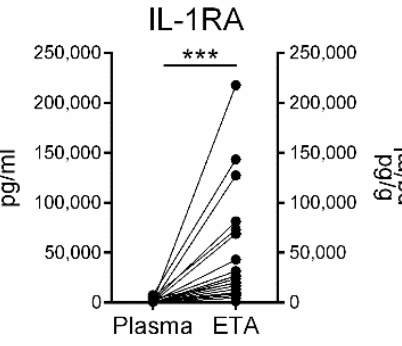

IFN- $\alpha 2$

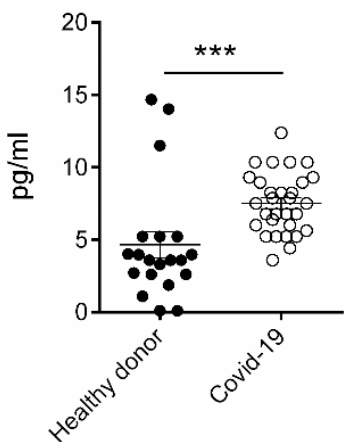

IFN- $\alpha 2$

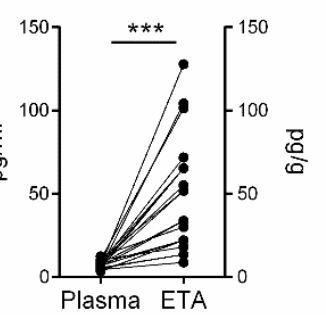

Figure 1: Inflammatory status of critically ill patients with Covid-19. A, Lymphocyte count in whole blood from critically ill Covid-19 patients $(\mathrm{n}=30)$ was analyzed at day 1 post admission. Individuals and means \pm SEM are depicted. B, Neutrophil-to-lymphocyte ratio in the whole blood of healthy donors $(n=20)$ and patients $(n=30)$ was determined by flow cytometry. Individuals and means \pm SEM are shown. C, Spearman's rank correlation of SOFA and lymphocyte counts in Coiv-19 patients. D, Lymphocyte counts at day 1 in patients with (n $401=21)$ or without $(\mathrm{n}=9)$ mechanical ventilation. Individuals and means \pm SEM are depicted. $\mathbf{E}$, Levels of IL-1 $\beta$, IL-6, IL-1RA and IFN- $\alpha 2$ in the plasma of healthy donors $(n=10)$ and severe Covid-19 patients $(n=30)$. Individuals and means \pm SEM are shown. $\mathbf{F}$, Levels of IL-1 $\beta$, IL-6, IL-1RA and IFN- $\alpha 2$ in the plasma and ETA supernatants of matched patients. Paired individual values are shown. $* *, \mathrm{p}<0.01 ; * * *, \mathrm{p}<0.001$. 
A

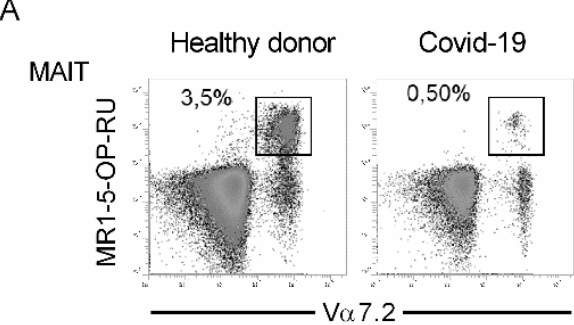

iNKT

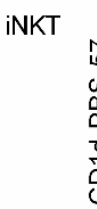

$\gamma \delta \mathrm{T}$
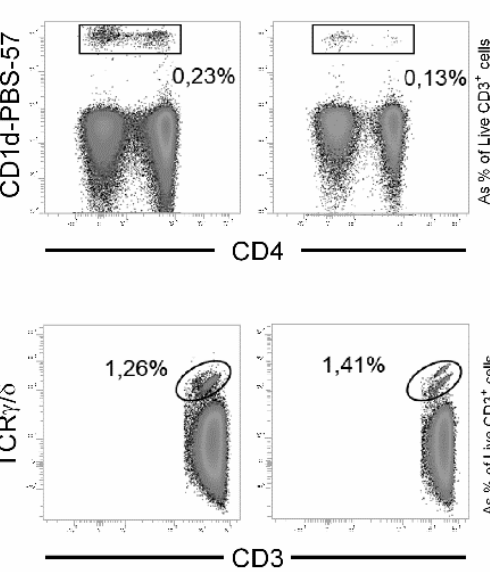

$\gamma \delta \mathrm{T}$

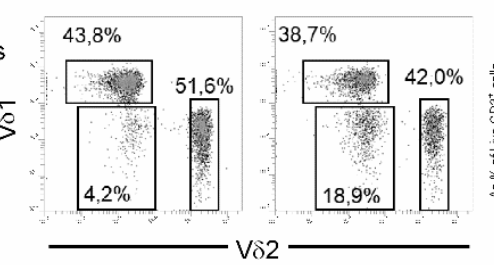

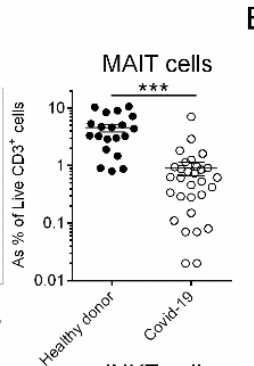

iNKT cells

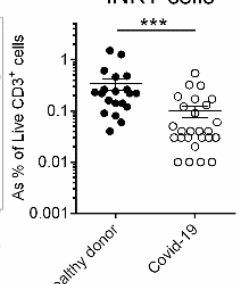

$2^{20^{2}} \gamma \delta \mathrm{T}$ cells

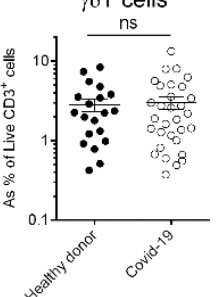

$\gamma \delta$ T subsets

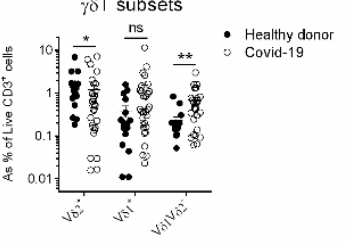

C
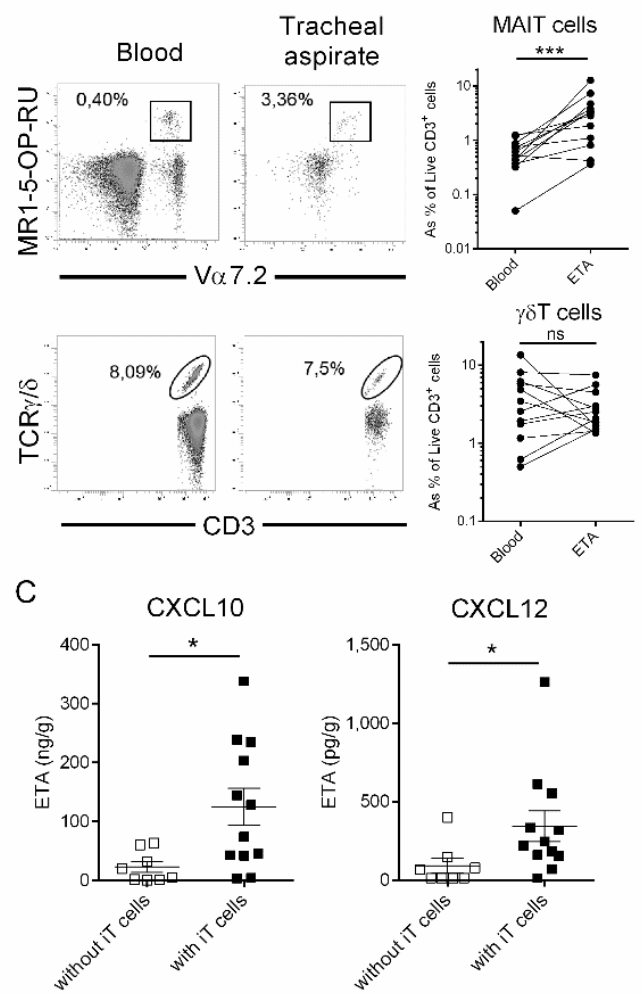

407

Figure 2: Relative proportion of innate $T$ cells in PBMC and ETA of Covid-19 patients.

A, Flow cytometry analyses of innate T cells in the blood of healthy donors $(n=20)$ and severe Covid-19 patients $(n=30)$. Representative dot plots of MAIT, iNKT and $\gamma \delta$ T cells from healthy donors and Covid-19 patients as percentage of $\mathrm{CD}^{+}$live cells are shown in the left panel. Proportion of $\gamma \delta \mathrm{T}$ subsets is shown as percentage of total $\gamma \delta \mathrm{T}$ cells. Individuals and means \pm SEM are shown in the right panel. Of note, iNKT cells could not be detected in 4 patients. B, Comparative analysis of MAIT and $\gamma \delta \mathrm{T}$ cell subsets in blood and ETA of 12 Covid-19 patients with analyzable lymphocyte compartment in ETA. Representative dot plots are shown in the left panel. Individuals and means \pm SEM are shown in the right panel. C, Levels of CXCL10 and CXCL12 in ETA supernatants according to the presence $(n=12)$ or not $(n=8)$ of iT cells. Individuals and means \pm SEM are shown. ns, not significant; *, p<0.05; ***, p<0.001. 

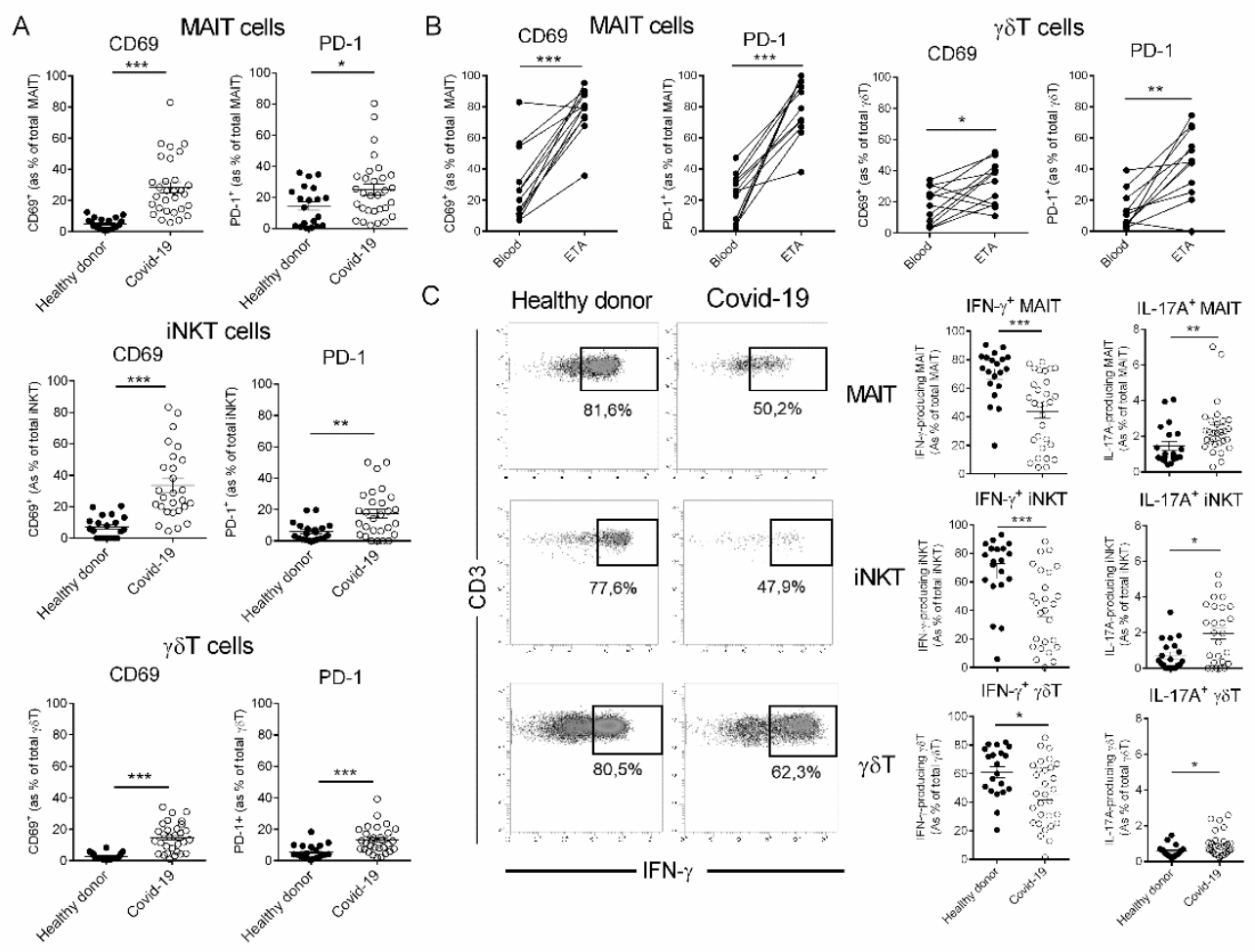

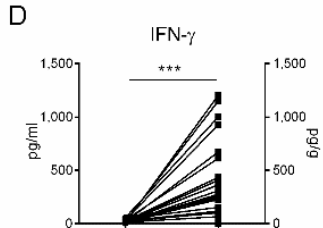

IL-17A

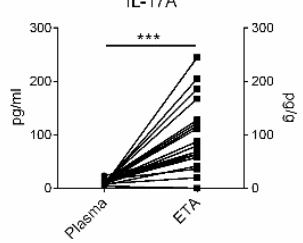

E

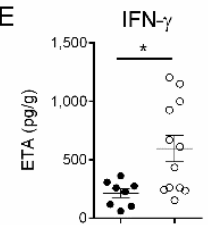

IL-17A

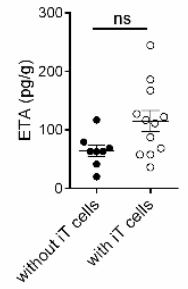

Figure 3
422

Figure 3: Functional analysis of innate $T$ cells during severe Covid-19. A, Flow cytometry analyses of CD69 and PD-1 expression on MAIT, $\gamma \delta$ T and iNKT cells in the blood of healthy donors $(n=20)$ and severe Covid-19 patients $(n=30)$. Individuals and means \pm SEM are shown. B, Relative proportions of $\mathrm{CD} 9^{+}$and PD- $1^{+}$iT cells in the blood and ETA of matched patients. Paired individual values are shown. C, Intracellular staining for IFN- $\gamma$ and IL-17A of PMA/ionomycin-activated PBMC. Representative dot plots for iT cells are depicted in the left panel. Individuals and means \pm SEM are shown on the right panel. D, Levels of IFN- $\gamma$ and IL$17 \mathrm{~A}$ in the plasma and ETA supernatants of matched patients. Paired individual values are shown. E, Levels of IFN- $\gamma$ and IL-17A in the ETA supernatants according to the presence $(\mathrm{n}=$ $12)$ or not $(n=8)$ of iT cells. ns, not significant; *, p<0.05; **, $p<0.01 ; * * *, p<0.001$. 
A

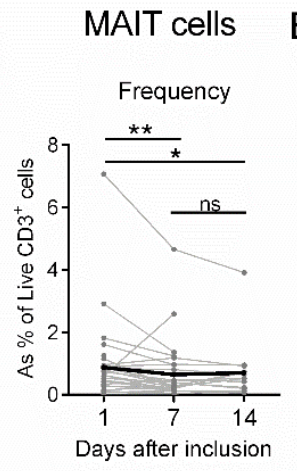

CD69

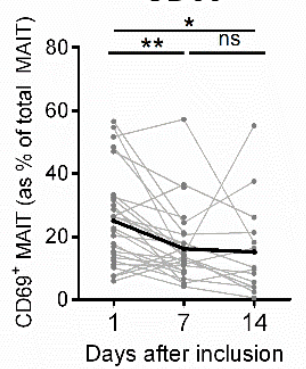

PD-1

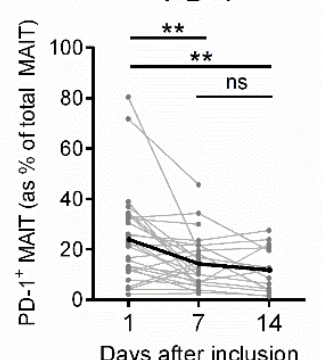

Days after inclusion

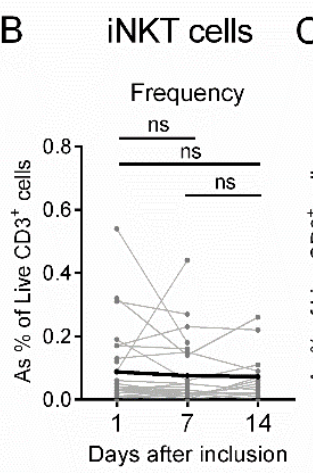

CD69

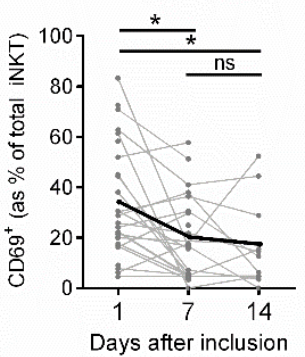

PD-1

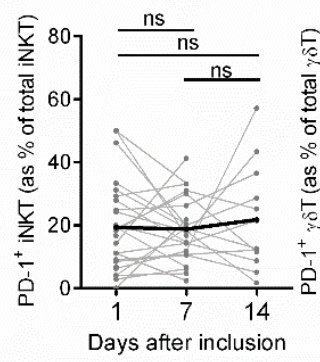

D

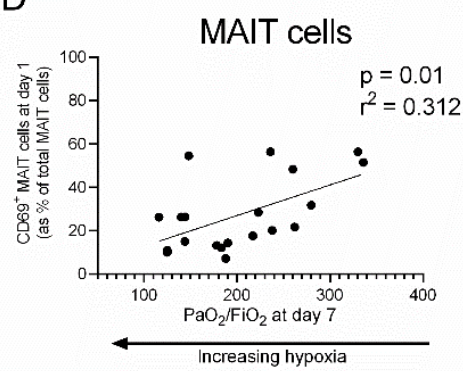

C $\quad \gamma \delta \mathrm{T}$ cells

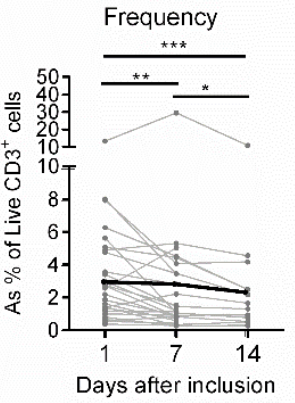

CD69

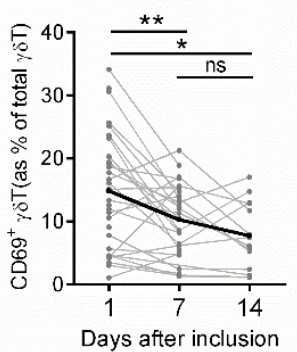

PD-1

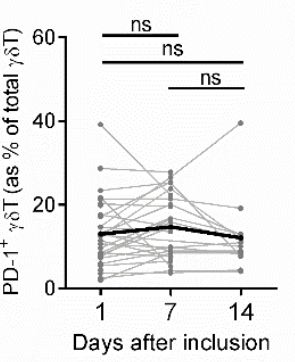

iNKT cells

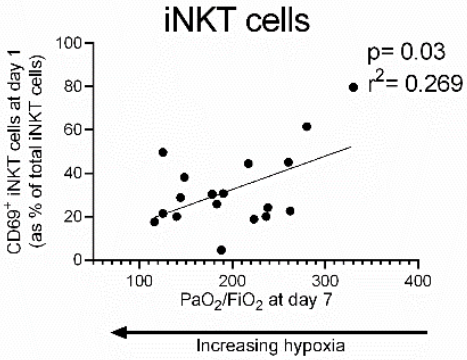

Figure 4: Kinetic analysis of the frequency and phenotype of innate $T$ cells in severe

Covid-19 patients. A-C, Flow cytometry analyses of relative proportion and CD69 and PD-1 expression on MAIT (A), $\gamma \delta \mathrm{T}(\mathrm{B})$ and iNKT (C) cells in the blood of critically ill Covid-19 patients at days $1(\mathrm{n}=30), 7(\mathrm{n}=27)$ and $14(\mathrm{n}=14)$. Kinetics plots showing mean value for each patient (each grey line corresponds to one patient). Median values for each parameters were plotted in black. D, Spearman's rank correlation of CD69 expression on blood iT cells and hypoxia levels in Covid-19 patients. ns, not significant; *, p<0.05; **, p<0.01; ***, p<0.001. 
medRxiv preprint doi: https://doi.org/10.1101/2020.05.03.20089300; this version posted May 6, 2020. The copyright holder for this preprint (which was not certified by peer review) is the author/funder, who has granted medRxiv a license to display the preprint in perpetuity.

All rights reserved. No reuse allowed without permission.

443

\begin{tabular}{|c|c|}
\hline Age (years), median (IQR) & $64(57 ; 67)$ \\
\hline Male / Female ratio & $2 / 1$ \\
\hline Body Mass Index $\left(\mathrm{kg} / \mathrm{m}^{2}\right)$ & $31(28 ; 32)$ \\
\hline \multicolumn{2}{|l|}{ Comorbidities } \\
\hline Hypertension, n (\%) & $12(46.7)$ \\
\hline Type 2 diabetes & $9(30)$ \\
\hline Active smoking & 0 \\
\hline Chronic respiratory failure & 0 \\
\hline Chronic renal failure & $1(3.3)$ \\
\hline Cardiovascular disease & $3(10)$ \\
\hline Immunosuppression & $1(3.3)$ \\
\hline SAPS2 & $32(22 ; 36)$ \\
\hline SOFA & $4(2 ; 6)$ \\
\hline Invasive mechanical ventilation on admission & $20(66.7)$ \\
\hline \multicolumn{2}{|l|}{ Laboratory data } \\
\hline Lymphocytes $\left(\times 10^{9} / \mathrm{L}\right)$, median (IQR) & $0.715(0.510 ; 0.998)$ \\
\hline Neutrophils $\left(\mathrm{x} 10^{9} / \mathrm{L}\right)$, median $(\mathrm{IQR})$ & $6.25(4.3 ; 7.52)$ \\
\hline CRP (mg/L), median (IQR) & $187.7(83.8 ; 258)$ \\
\hline
\end{tabular}

Table 1:.Clinical and laboratory information of the study patients. 


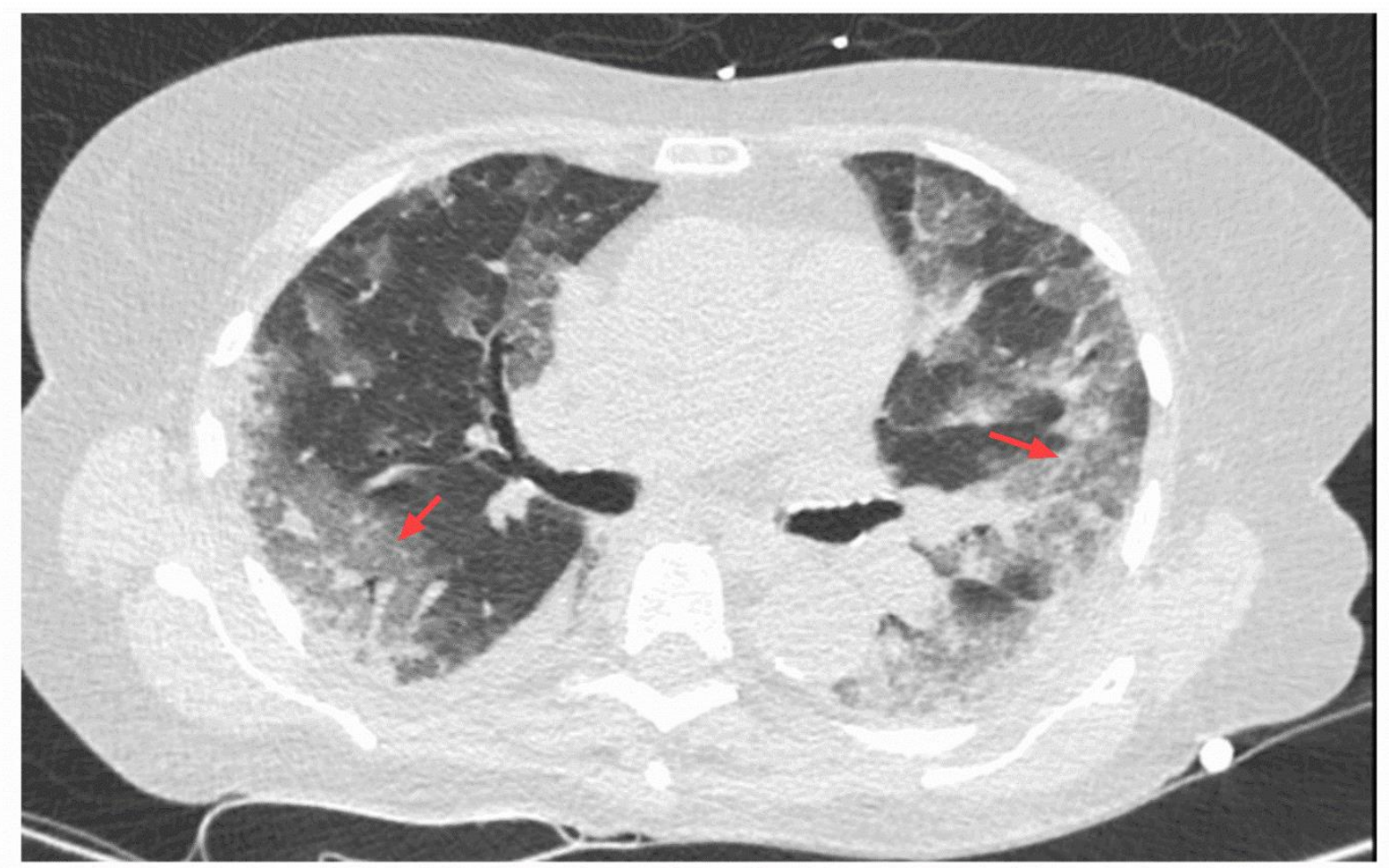

Covid-19 patient.

A

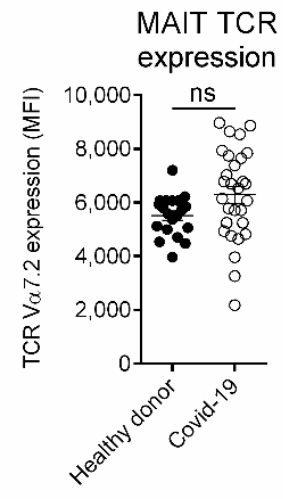

B

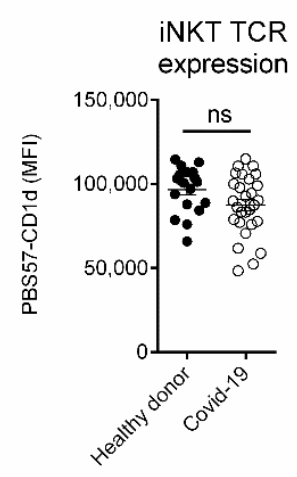

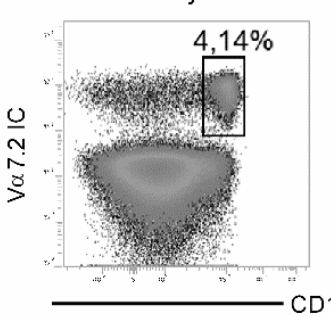

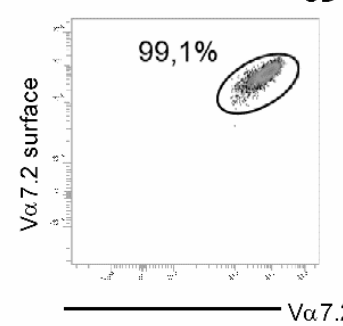

Covid-19

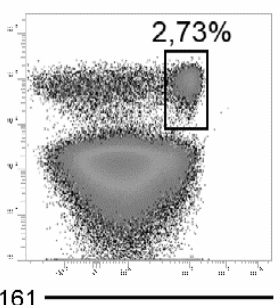

$99,4 \%$

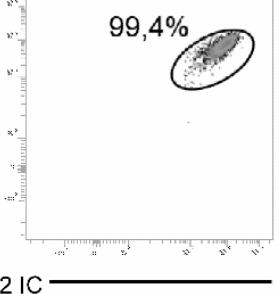

\section{Supplemental Figure 2: Evaluation of TCR internalization in MAIT and iNKT cells. A,}

Mean intensity fluorescence of TCR expression on MAIT and iNKT cells from control $(n=20)$ or Covid-19 patients $(\mathrm{n}=30)$ based on TCR Va7.2 and PBS57-CD1d tetramer staining respectively. Individuals and means \pm SEM are shown. B, Flow cytometry analysis of TCR Va7.2 expression using surface $v s$ intracellular staining. Representative dot plots of 4 control and 4 Covid-19 patients are shown. ns, not significant; $* * *, p<0.001$. 


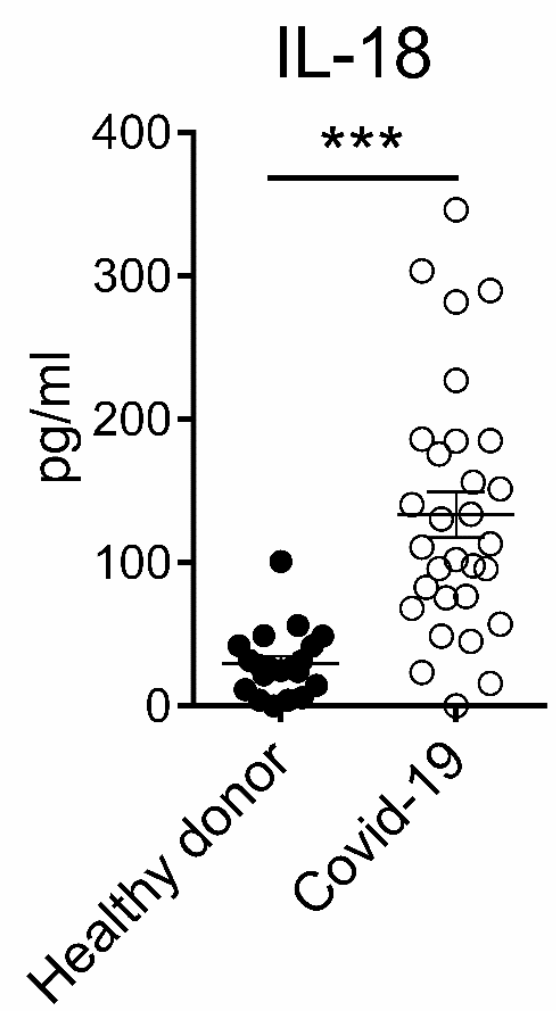

458 Supplemental Figure 3: Plasma levels of IL-18 in critically ill Covid-19 patients. Levels of 459 IL-18 in the plasma of healthy donors $(\mathrm{n}=10)$ and severe Covid-19 patients $(\mathrm{n}=30)$. 460 Individuals and means \pm SEM are shown. ***, $\mathrm{p}<0.001$. 
medRxiv preprint doi: https://doi.org/10.1101/2020.05.03.20089300; this version posted May 6, 2020. The copyright holder for this preprint (which was not certified by peer review) is the author/funder, who has granted medRxiv a license to display the preprint in perpetuity.

All rights reserved. No reuse allowed without permission.

462 Supplemental Table 1: List of anti-human monoclonal antibodies

463

\begin{tabular}{|c|c|c|c|}
\hline Epitopes & Clone & Fluorophore(s) & Manufacturers \\
\hline CD3 & OKT3 & APC & BioLegend \\
\hline IL-17A & BL168 & APC & BioLegend \\
\hline CD45 & 2 D1 & APC/Cy7 & BioLegend \\
\hline CD4 & OKT4 & APC/Cy7 & BioLegend \\
\hline TCR V $\boldsymbol{2} 2$ & B6 & FITC & BioLegend \\
\hline TCR Va7.2 & 3 C10 & FITC & BioLegend \\
\hline CD3 & HIT3a & FITC & BioLegend \\
\hline IFN- $\boldsymbol{\gamma}$ & 4 S.B3 & PE & BioLegend \\
\hline CD69 & FN50 & PE & BioLegend \\
\hline PD-1 & A17188B & PE-Cy7 & BioLegend \\
\hline CD161 & HP-3G10 & PerCP & BioLegend \\
\hline TCR $\boldsymbol{\gamma} / \boldsymbol{\delta}$ & B1 & PerCP-Cy5.5 & BioLegend \\
\hline TCR V $\boldsymbol{\delta} 1$ & REA173 & VioBlue & Miltenyi Biotec \\
\hline
\end{tabular}

